\title{
THE REQUIREMENT OF EMPLOYMENT UNDER AN EMPLOYMENT RELATIONSHIP IN PUBLIC PROCUREMENT AND THE PROTECTIVE FUNCTION OF THE LABOUR LAW
}

\begin{abstract}
The issues included in the article focus on a tool ensuring compliance with provisions of the social law and labour law, as well as collective agreements (so-called cross-cutting "social clause" or horizontal clause) and more precisely on the analysis of regulations of Polish Public Procurement Law related to the requirement posed in relation to economic operators or subcontractors, concerning mandatory employment of staff under an employment relationship when they execute public procurement contracts. The regulation fulfils the protective function of the labour law, underlying the priority of employment. It was emphasized that socially responsible public procurement are inseparably connected with compliance with the provisions of the labour law, whose main aim is to protect the employee. The article also analyses selected issues concerning socially responsible public procurement and the notion of an employment relationship.
\end{abstract}

Słowa kluczowe: umowy o zamówienie publiczne, stosunek pracy, funkcja ochronna prawa pracy, zamawiający, wykonawca, społecznie odpowiedzialne zamówienia publiczne

Keywords: public contracts, employment relationship, protective function of the labour law, contracting authority, economic operator, socially responsible public procurement

ASJC: 3308, JEL: K31

\section{Social issues in public contracts-general remarks}

Public contracts meant contracts for pecuniary interest concluded between a contracting authority (in principle a public entity) and an economic operator (in principle a private entity), having as their subject-matter services, supplies or (construction) works. They are aimed directly at optimum spending of public funds in order to satisfy social needs. 
At the same time, since they play a significant role in the economic trading, ${ }^{1}$ they should form an instrument enabling positive effects to be achieved in the sphere of social policy (implemented in particular by state and local government entities), which is closely related to the constitutional principle of social market economy (Art. 20 of the Constitution of the Republic of Poland of 2 April 1997, Dz.U. 1997, No. 78, item 483 as amended, hereinafter referred to as: "the Constitution"). The objectives of this principle are indicated as social security, social justice, including the social assistance system and the guarantee of full employment (Jacolik 2017, pp.61-62). The reference to the model of social market economy assuming an obligation to implement both the principle of freedom of competition and the principle of social justice is also present in the EU legislation (Art. $3 \mathrm{sec} .3$ of the Consolidated version of the Treaty on European Union, OJ C 2012/326, pp. 13-390) and in other EU documents containing programme assumptions, with a significant position of Europe 2020 strategy (Communication From The Commission, Europe 2020, A strategy for smart, sustainable and inclusive growth, COM (2010) 2020 final) substituting the Lisbon strategy. According to its assumptions, the EU approach to the social policy has changed to highlight the need to create new jobs rather than to focus only on the protection of employment (Barnard 2012, p. 25). Public procurement was defined expressis verbis as one of the market instruments used to achieve permanent economic growth through the introduction of sustainable economic policy preventing social and economic exclusion, aimed at the creation of new jobs and improvement of conditions of employment (Moras, Moras-Olaś 2017, p. 14). Analogical conclusions are drawn from national programme documents (e.g. strategy "Efficient State 2020," Strategy for Responsible Development until 2020, with a perspective until 2030). Public procurement is not only a legal instrument but also a social and economic instrument for the state. Thus, besides playing the role of the legislator providing the normative grounds for socially responsible public procurement and a guard of legal compliance, the state is also an entity that actively influences that market (Odachowski 2019, pp. 40-41). Therefore, during public procurement various social needs should be taken into account, in particular, the ones related to combating unemployment, a guarantee of fair salaries or preventing social exclusion (Moras, Moras-Olaś 2017, p. 14). This is called socially responsible public procurement.

Respective legal regulations implementing the assumptions specified above were included in the EU and national legal acts on public procurement. They were also included in directives dated 2004 on public procurement (Dzierżanowski 2012, p. 30), and now they are widely regulated by the directives dated 2014 (Directive 2014/24/EU of the European Parliament and of the Council of 26 February 2014 on public procurement and repealing Directive 2004/18/EC, OJ L 2014/94, pp. 65-242; Directive 2014/25/EU of the European Parliament and of the Council of 26 February 2014 on procurement by entities operating in the water, energy, transport and postal services sectors and

1 According to the report of the Chairperson of Public Procurement Office for 2019 (UZP 2020, p. 7), public procurement accounted for $8.75 \%$ of the gross national product. 
repealing Directive 2004/17/EC, OJ L 2014/94, pp. 243-374; Directive 2014/23/EU of the European Parliament and of the Council of 26 February 2014 on the award of concession contracts, OJ L 2014/94, pp. 1-64). Solutions aimed to take account of social aspects in public procurement may be divided into tools supporting social and occupational integration, ensuring compliance with provisions of the social law and labour law, as well as collective agreements (so-called cross-cutting "social clause" or horizontal clause). Moreover, social aspects may be included in the description of the subject of procurement (and also its execution), as well as the criteria of bid assessment, taking account, simultaneously, of the principle of purpose limitation and efficiency of procurement (Szostak 2017, p. 350). ${ }^{2}$

The issues included in this article focus on the horizontal clause mentioned above, and more precisely on the analysis of Polish legal regulations related to the requirement posed in relation to economic operators or subcontractors and concerning mandatory-if the normative prerequisites are fulfilled-employment of staff under an employment relationships when they execute public procurement contracts. This regulation fulfils the protective function of the labour law, underlying the priority of employment. At the same time, it intends to eliminate pathological cases of work performed with violation of Art. $22 \$ 1^{1}$ of the Labour Code (Act of 26 June 1974, Dz.U. 2020, item 1320 consolidated text, as amended, hereinafter referred to as: "the Labour Code.")

\section{The requirement of employment under an employment relationship}

Analysing the national regulations, it should be noted that the obligation to comply with the labour and social insurance law was defined already in the Act of 10 June 1994 on Public Procurement Law (Dz.U. 2002, No. 72, item 664 consolidated text, as amended) (Szostak 2017, p. 305). Taking into account the subject of this article, the amendment of the Act of 29 January 2004 on Public Procurement Law (Dz.U. 2019, item 1843 consolidated text, as amended) is significant, while it introduces a possibility of optional reservation of employment under an employment contract in the terms of reference of a public contract for services or works, if performance of a contract includes activities justifying such type of employment (the Act of 29 August 2014 on amendment of the Public Procurement Law, Dz.U.2014, item 1232). As a result of the next amendment, this requirement became mandatory (the Act of 22 June 2016 on

2 Besides the Act of 11 September 2019 on Public Procurement Law (Dz.U. 2021, item 1129 consolidated text, as amended, hereinafter referred to as: "new Public Procurement Law," "nPPL") the principle of purpose limitation and efficiency of procurement and the manner of spending of public funds are defined in Art. 44 of the Act of 27 August 2009 on Public Finance (Dz.U. 2021, item 305 consolidated text, as amended) in the light of which "managing public funds is open and public spending should be made in a purposeful and cost-effective manner, ensuring the rules of achievement of best effects from the expenditure made." 
amendment of the Public Procurement Law and other acts, Dz.U. 2016, item 1020). According to the legal regulation amended at that time, in the description of a subject of a public contract for services or works, the contracting authority defined requirements concerning employment of persons carrying out specific activities during execution of a contract under an employment contract by an economic operator or subcontractor, if carrying out of such activities means the performance of work in the way specified in Art. $22 \$ 1$ of the Labour Code. Compliance with this provision in practice proved to be a difficult task for parties of award procedure for public contracts (Piwowarczyk 2017, pp. 53-54), with a particularly controversial aspect of control of the discussed requirement by contracting authorities in the light of the provisions on personal data protection (see Moras, 2016, pp. 331-332; Dzierżanowski 2017, pp. 35-37; Moras, Moras-Olaś 2017, pp. 743-747). At the same time, due to the fact that the requirement of employment under an employment contract in case of fulfilment of the statutory prerequisites was mandatory, the discussed clause was the social instrument most often used in practice among other ones defined by law. ${ }^{3}$ It also refers to the contracting authorities belonging to the government administration, whose main task is to reduce social problems and to combine economic growth with better living standards. Special recommendations were issued for those contracting authorities, which obligated the heads of government administration entities to take account of social aspects as broadly as possible in the biggest number of public procurement procedures. It was affirmed that public procurement contracts and de facto funds spent because of contracts granted by the contracting authorities belonging to the government administration may have a significant impact on the fulfilment of State socio-economic policy.

The new Public Procurement Law, which has been in force since $1^{\text {st }}$ January 2021 also provides that the contracting authority defines-in a public contract notice or documents of a contract for services or works-the requirements concerning the employment of persons carrying out activities indicated by the contracting authority during execution of a public contract under an employment relationship by an economic operator or a subcontractor, if performance of such activities means the performance of work in the way defined in Art. $22 \$ 1$ of the Labour Code (Art. 95 of the nPPL). The provision defined that the requirement of employment under an employment relationship does not refer to contracts for supplies, but only contracts for services ${ }^{4}$ or works. ${ }^{5} \mathrm{~A}$ group of

3 It is confirmed by the data presented in the report of the Chairman of the Public Procurement Office for the years 2017-2018. For example, in 2019 the number of contracts containing the requirement of employment under an employment contract amounted to 25333 out of 28071 contracts that took account of social aspects, and the value of those contracts without VAT amounted to PLN 57191315222.85 (UZP 2020, pp. 51-53).

4 Article 95 of nPPL refers also to contracts for social services and other special services, such as security services, legal services, cleaning services due to provisions of Art. 359 of nPPL. The definition of services is included in Art. 7 point 28 of nPPL.

5 The definition of works is included in Art. 7 point 21 of nPPL. 
entities obliged to fulfil this requirement was broadly defined, including subcontractors ${ }^{6}$ besides an economic operator. ${ }^{7}$ Therefore, if an economic operator executes a public contract by subcontractors, it should have an appropriate provision defining that the employment requirement specified in a public contract notice or in public contract documents refers also to persons appointed by a subcontractor performing a contract. The contracting authority is also obliged to specify-in contract documents-types of activities related to the execution of a contract, which are subject to the requirement of employment under an employment relationship, the manner of verification of the employment, and also rights of the contracting authority related to control the employment, and sanctions in case of failure to fulfil these requirements. The obligation to specify activities requiring employment under an employment relationship refers at the moment to activities "related" to its execution, not like previously to "essential activities," which seems to imply a wider catalogue of activities defined by a contracting authority, both in a positive or a negative manner (Dzierżanowski 2017, p. 32). At the same time, it should be noted that the literature on the subject and the official opinion express the need to create a positive catalogue, and consequently specification of all activities, to which the requirement of employment under employment relationship refers (UZP 2017b; Matusiak 2021; Art. 95 of nPPL). ${ }^{8}$ In particular, in the case of public contracts for works, within which a wide group of works is performed, it is a difficult and time-consuming task. The contracting authority, as a party organising public procurement was thus obligated to perform an analysis of all activities carrying out under a public contract, and this should result in a delimitation of activities performed under an employment relationship to those, in case of which an economic operator has (relative) freedom to select a manner of employment taking into account the factual

6 A subcontractor should be understood as an entity that concluded a subcontract defined in Art. 7 point 27 of nPPL, which means that in case of construction work contracts the obligation defined in Art. 95 of nPPL refers also to further subcontractors, while in the case of services it refers only to an entity that has entered into a direct contract with a contractor. Subcontractor's (even further subcontractor's) obligations include execution of a part of a contract, so it is a party actually performs a defined part of a contract against a fee.

7 A contractor should be understood as an individual, legal entity or an organisational entity without legal personality that offers execution of construction services or construction, delivery of product or performance of services or applies for a contract, has submitted a bid or concluded a public procurement contract (Art. 7 point 30 of nPPL).

${ }^{8}$ In the light of the still up-to-date opinion of the Chairman of the Public Procurement Office "while finding activities of the nature of activities defined in the Labour Code, the contracting authority will be obliged to specify all such activities. It would be contradictory to Art. 29 section 3a of the Public Procurement Law (now it is Art. $95 \mathrm{nPPL}$ ) to specify some activities only, although they are of great importance for the contracting authority, and to omit others, e.g. of minor importance. It is not acceptable to ... delegate this obligation to the contractor, e.g. in form of a provision that if the contractor reveals activities of such nature on its side, it will be obliged to enter into an employment contract with employees who perform them, and to specify, too generally, that the contracting authority requires employment under employment relationship for all persons performing activities of such nature during the execution of the contract." 
circumstances of the public procurement concerned. Nevertheless, the contracting authority is limited in this field. If prerequisites defined in Art. $22 \$ 1$ of the Labour Code are fulfilled, a contracting authority is obliged to require employment under an employment relationship (judgment of the National Appeal Chamber of 7 February 2017, KIO 191/17; see also: Granecki 2021; Art. 95 of the nPPL; Matusiak 2021; Art. 95 of the nPPL). A possibility of other employment than under an employment relationship must be preceded with an analysis of nature of activities to be performed in relation to the execution (e.g. an achievement of a specific result), and even features of entities that perform them, e.g. having special rights (UZP 2017b). It is reasonable particularly when relative independence may be assigned to a person engaged for the execution of a contract (Szostak 2017, p. 356). In this respect, a question may be raised, on the potential effectiveness of a differentiation of activities performed on the basis of an employment under and without an employment relationship made by a contracting authority in the context of Art. $22 \$ 1^{1}$ of the Labour Code. Specifying that a certain kind of work is performed for the employer (under remuneration), under its supervision, in the place and time specified by the employer, is sufficient for determination of an employment relationship (e.g. judgment of the Supreme Court of 24 June 2015, II PK 189/14, Legalis 1303584). The factual conditions of execution of the agreement (a manner how a legal connection is shaped during a legal relationship) are important regardless of the name of an agreement and the content declared upon conclusion of an agreement (decision of the Supreme Court of 12 September 2019, SN II UK 210/19, LEX 2763433). Thus, even a contracting authority's decision that activities concerned do not need to be performed under an employment relationship shall not waive the above mentioned regulation.

It should be added that the requirement of employment under an employment relationship must not lead to discrimination of self-employed economic operators who intend to perform a public procurement contract on their own, which may take place mainly in the case of lower value procurements. The analysed requirement refers to the cases, where persons performing activities related to an execution of a contract are employed by an economic operator or a subcontractor. Another interpretation could lead to disfavouring of economic operators due to the legal form of their businesses, which is contradictory to a normative definition of a term of an economic operator (see Art. 7 point 30 of nPPL). These remarks refer also to partners of partnerships, which is confirmed by the case law, according to which: "In respect to a partnership, where partners carrying out work on their own regarding activities specified by the contracting authority, it is not possible to comply with the obligation to employ such persons under employment contracts" (judgment of the National Appeal Chamber of 22 October 2019, KIO 1988/19; judgment of the National Appeal Chamber of 24 November 2016, KIO 2101/16). It is also pointed out that civil law contracts, and mainly the contract for specific work, may be applied "when the reasonable share of employee's activities in the execution of a contract is minute, limited only to supervisory activities over a subcontractor acting as an individual craftsman or another small entrepreneur, for 
whom a contract for specific work would be more convenient, e.g. in case of repairs, installation of devices, the performance of an item of equipment upon order" (Szostak 2017, p. 356).

The literary interpretation of these requirements, enhanced by the proportionality principle of the new Public Procurement Law objects to verification of the employment under employment relationship at an economic operator or a subcontractor when they apply for a public contract, that is before a public contract is executed (Lang 2014, p. 108; Szostak 2017, p. 356; judgment of the National Appeal Chamber 29 January 2018, KIO 74/18). At the stage of a public procurement procedure, economic operators only declare fulfilment of this requirement. Moreover, it is deemed unacceptable to determine at least a minimum number of persons employed under an employment relationship (UZP 2017a). Due to the fact, that at the stage of a public procurement procedure an economic operator only declares fulfilment of the requirement of employment under an employment relationship defined by the contracting authority, it must be verified at the stage of performance of a public contract. Therefore, in public contracts for services or works, mandatory contractual clauses should be included, and they should refer to the manner of documentation of employment, an inspection of an economic operator's or a subcontractor's fulfilment of requirements concerning an employment and sanctions for failure to meet these requirements (Art. 438 of the nPPL). Taking into account postulates presented by representatives of the doctrine, the legislator indicated precisely that verification of fulfilment of the requirement of employment under an employment relationship covers both an economic operator and a subcontractor. The legislator specified also examples of document types that may be demanded by contracting authorities for verification of employment (e.g. declaration of an employee) and defined personal data that may be processed by the contracting authority in relation to such verification. It should be mentioned that the contracting authority's rights for verification and control are limited to these activities, in case of which the requirement of employment under an employment relationship has been indicated in a public contract notice or contract documents. If at the stage of execution of a contract, the contracting authority has doubts about grounds of employment of other persons who perform work, it may request for a control to be performed by a competent authority, that is the State Labour Inspection Office. However, an inspection of the State Labour Inspection Office has a general nature and it is related to the employer's activities, but not a performance of a specific public procurement contract (Moras, Moras-Olaś 2017, pp. 745-748). Unlikely Art. 95 of nPPL that refers to an employment relationship, Art. 438 of nPPL that specifies requirements for content of a public contract refers to evidence of employment and control the fulfilment of requirements for employment under an employment contract. It would mean that the mandatory contractual elements should refer only to such employment, which may raise a concern of inconsistency between legal provisions within one normative act. Therefore, a change in this respect should be requested, provided that in general non-contractual grounds of employment, such as an appointment, an election or a nomination are not used in private entities 
that in principle are economic operators or subcontractors of public contracts, just like a cooperative employment contract that occurs increasingly more occasionally (Stelina 2017 , pp. 137, 139, 143, 144). In practice, this regulation will in fact refer, apparently, to employment under an employment contract.

The employment of workers ${ }^{9}$ employed by foreign employers performing public contracts in Poland is still not fully solved. It would be a requirement that violates the principle of the free movement of services for such persons to be compulsorily employed in Poland based on Polish labour law provisions (Dzierżanowski 2017, p. 35). At most, these provisions shall establish a minimum standard of protection. In the light of provisions of the Directive 2014/24/EU Member States shall take appropriate measures to ensure that in the performance of public contracts economic operators comply with applicable obligations in the fields of social and labour law established by Union law, national law, collective agreements or by the international environmental, social and labour law provisions listed in Annex $\mathrm{X},{ }^{10}$ in particular with a view to ensuring equal treatment (Directive 2014/24/EU, Art. 18(2)). It is also indicated that such relevant measures shall be applied in accordance with Directive 96/71/EC of the European Parliament and of the Council of 16 December 1996 concerning the posting of workers in the framework of the provision of services (OJ L 1997/18, pp. 1-6) and in a way that ensures equal treatment and does not discriminate directly or indirectly against economic operators and workers from other Member States (recital 36 of Directive $2014 / 24 / \mathrm{EU}$ ). When analysing the basis of employment, one should consider, that the concept of "worker" has an autonomous specific meaning, accepted by recent case law of the CJEU ${ }^{11}$ (Świątkowski 2014, pp. 567-572; Świątkowski 2019, pp. 47-55). It was created for the purpose of EU law-to guarantee rights under EU law for all groups of active persons. The employment relationship under national law cannot have any consequences in regard to whether or not the person is a "worker" for the purpose of EU law (Świątkowski 2019, p. 57). It seems that the concept of "worker" is not applicable to the analysed provisions of the new Public Procurement Law. The discussed requirement of employment under an employment relationship in public contracts is an initiative of

9 In this paper, the notions of "worker" and "employee" are used interchangeably.

${ }^{10}$ The Annex X includes the list of international social and environmental conventions referred to in Art. 18(2), which are in particular: ILO [International Labour Organization] Convention 87 on Freedom of Association and the Protection of the Right to Organise; ILO Convention 98 on the Right to Organise and Collective Bargaining; ILO Convention 29 on Forced Labour; ILO Convention 105 on the Abolition of Forced Labour; ILO Convention 138 on Minimum Age; ILO Convention 111 on Discrimination (Employment and Occupation); ILO Convention 100 on Equal Remuneration; ILO Convention 182 on Worst Forms of Child Labour.

${ }^{11}$ In one of the cases the CJEU has defined the "worker" as: "any person who pursues activities that are real and genuine, to the exclusion of activities on such a small scale as to be regarded as purely marginal and ancillary ... The essential feature of an employment relationship is, according to that case law, that for a certain period of time a person performs services for and under the direction of another person in return for which he receives remuneration" (judgment of the CJEU of 1 October 2015, C-432/14, O v. Bio Philippe Auguste SARL, EU:C:2015:643 \$22). 
the Polish legislator, not specified in the EU law. As it was mentioned, it was introduced into the new Public Procurement Law to eliminate pathological cases of work performed with violation of Art. $22 \$ 1^{1}$ of the Labour Code, in particular the use of employment under civil law instead of employment under an employment relationship.

\section{The notion of an employment relationship-selected issues}

The foregoing requirement of employment under an employment relationship requires a brief reference to the notion of an employment relationship regulated in the Labour Code. According to Art. 2 of the Labour Code, a worker is a person employed on the basis of an employment contract, an appointment, an election, a nomination or a cooperative employment contract. The ground for the establishment of employment relationships is thus the most important criterion enabling differentiation of contractual relationships (employment contract) and non-contractual relationships. According to Art. $22 \S 1$ of the Labour Code, by the establishment of an employment relationship the employee shall oblige himself/herself to perform specific work for the employer, under his/her supervision, at the place and time specified by the employer, and the employer-to employ the worker for remuneration. Discussed Art. 95 of nPPL refers de facto only to contractual employment relationships. A relationship created as a result of the conclusion of an employment contract is the basic type of an employment relationship, which means that unlikely non-contractual employment relationships, its conclusion does not require detailed legal grounds (Stelina 2017, p. 120). Moreover, it is pointed out that it is "a real paradigm for other types of employment relationships" (Stelina 2017, p. 120).

The above-quoted legal definition of an employment relationship included in Art. $22 \$ 1$ of the Labour Code (Wagner 2011, p. 157; Stelina 2017, p. 121; Tomaszewska 2020; Art. 22 of the Labour Code) defines the attributes of the employment relationship, its contents, subjects and mutual relations between a worker and an employer (Tomaszewska 2020; Art. 22 of the Labour Code). Although this definition is only of partial nature, the liabilities of the parties defined therein constitute the core of the employment relationship as a bilateral relation, whose conclusion requires mutual declarations of will to be made (resolution of the Supreme Court of 9 September 1986, III PZP 37/86, OSN 1987, No. 9, item 134). Specified elements of the employment relationship serve at the same time as the criteria enabling differentiation between an employment relationship and other legal relationships that form admissible grounds for the performance of work, such as civil law contracts. The constitutive attributes of the employment relation include: "voluntary nature, personal performance of work in a continuous manner, subordination, performance of work for an employer who bears the risk related to employment, as well as paid nature of employment" (Tomaszewska 2020; Art. 22 of the Labour Code and the case law quoted therein). According to the view presented in the doctrine these features should be fulfilled cumulatively, provided that 
depending on all factual circumstances of a given case, it may be achieved to a different extent (Lewandowski, Góral 1996, pp. 21 ff; Tomaszewska 2020; Art. 22 of the Labour Code). At the same time, it is emphasized that "the occurrence of all features of the employment relationship together is not necessary to consider an agreement as an employment contract, since the absence of some features may be compensated by the increased presence of other features" (decision of the Supreme Court of 12 September 2019, SN II UK 210/19, LEX 2763433).

Cumulative fulfilment of specified features may imply difficulties in determination of a border "between the aspects that have the decisive impact on the legal qualification of a given relationship, and aspects that are contradictory to the labour law and as such, without legal importance" (Stelina 2017, p. 133). The opinion on the introduction of a certain hierarchy of presented features should be considered right, and the key meaning should be assigned to the attributes that were defined expressis verbis in Art. $22 \$ 1$ of the Labour Code, that is a personal performance of work, a subordination of an employee and a remuneration (Stelina 2017, p. 133).

In the context of the discussed provision of the new Public Procurement Law, it should be noted that the Labour Code does not define the type of work that should be performed under an employment relationship only. For the qualification, whether we deal with an employment relationship, other elements specified above are decisive, not the type of work itself. Selection of a form of employment depends on the will of parties (subject to Art. $22 \S 1^{1}$ of the Labour Code), and therefore both employment under an employment relationship and otherwise is allowed. In some cases, however, according to the case law of the Supreme Court, the level and the manner of cooperation of many persons carrying out simple and unsophisticated actions in a technological process consisting of multiple tasks, that intertwine or cross with each other, is inseparably connected with subordination to the ongoing instruction of the person ordering performance of a joint task in respect to time and place, as well as the manner of their performance, which in fact requires employment under an employment relationship (see e.g. judgment of the Supreme Court of 18 February 2016, II PK 352/14, LEX 2004192). Thus the ad casum assessment is of key importance. So the requirement from the contracting authority to define types of activities performed under the employment relationship in an abstractive manner, regardless of the reality of a given case, having the subject of a contract in mind, may be very challenging for those authorities. In the case of the employment requirements, the type of activities performed by a worker is decisive, keeping however in mind the resignation of the contracting authority from a determination of the type of activities have no impact on the applicability of Art. $22 \S 1^{1}$ of the Labour Code. Contracting authorities have been assigned a difficult role, that was not present earlier in the Polish legislation, which interferes with a free will of the parties related to the grounds of performance of work, which was enhanced by the contracting authority's inspection rights at the stage of execution of public contract (see earlier remarks). Specific limitations are experienced by economic operators preferred other employment than under an employment relationship who due to formal, organisational, economic reasons, and a reduction of social costs 
(Szostak 2017, pp. 355-356). At the same time, the social aspects are the ratio legis of the requirement of employment under an employment relationship.

\section{The requirement of employment under an employment relationship and the protective function of the labour law}

It should be mentioned that despite presented objections, the discussed regulation fulfils the protective function of the labour law. In principles, it intends to limit the circumvention of Art. $22 \S 1^{2}$ of the Labour Code. It is obvious that when there is a legal relationship that has attributes of an employment relationship, it must always be concluded, but unfortunately, that is not often the case. The sufficient proof of it is the content of Art. $22 \$ 1^{2}$ of the Labour Code and numerous case law of the Supreme Court in this respect. At the same time, enforcement of this requirement is not easy and it is often related to a need to bring an action to court for a determination of the employment relationship. It requires an initiative of a worker or a labour inspector, who in turn has to have sufficient knowledge about such situation and the contracting authority may be the source of such knowledge. Thus the existence of an instrument that imposes an obligation to employ workers under an employment relationship by an economic operator and a possibility to control its fulfilment cannot be overestimated, in particular in respect to public procurement, in the situation of relatively frequent use of employment under civil law contracts that generated lower employment costs and consequently higher competitiveness of bids. Deterioration of quality of numerous places of work through for instance deprivation or limitation of employee status (e.g. temporary work) raises objections in the context of the constitutional principle of the social market economy (Skąpski 2014, p. 119; Męcina 2015, chapter 2.5). This principle provides grounds for the primary function of the labour law, that is the protective function (Męcina 2015, chapter 2.5), expressed in Art. 24 of the Constitution, in the light of which employment is under protection of the Republic of Poland, and the State supervises the conditions in which work is performed (Miętek 2019, chapter 4, $\$ 3$ ). The labour law is the exclusive "instrument of correction of the market mechanism in respect to the distribution of goods related to the performance of subordinate work" (Skąpski 2014, p. 112). Despite social transformations that take place, it is aimed at protection of an employee through a reduction of disproportion in the status of the parties of the employment relationship (Pisarczyk 2010, p. 17). Protection of life, health and dignity of a human as the subject of the employment process is mainly essential (Pisarczyk 2010, p. 18). A worker, depending economically and organisationally on an employer, who is the beneficiary of the work process deserves protection as the weaker party of a legal relationship (Pisarczyk 2010, pp. 17-18; Miętek 2019, chapter 4, \$3). The protective function consists in the introduction of "legal inequality" in favour of a worker (Święcicki 1969, p. 29) and ensuring basic (minimum) level of fair performance of work (Sobczyk 2013, chapter 1; Skąpski 2016, chapter 2.1). 
The symptom of the protective function is a semi-imperative nature of statutory norms determining the minimum level of employee rights and competencies, as the maximum level of employee obligations (Skąpski 2016, chapter 2.1; Gersdorf 2018, p. 82). They may be changed only in favour of an employee. The protective function of the labour law is widely implemented by the provisions on work safety and hygiene. Legal regulations related to particularly protected employees, e.g. parents, young or disabled employees are also essential. In respect to the individual labour law, the discussed function is performed for instance by the provisions on working time, holidays, limitation of employee's financial liability, protection of the durability of the employment relationship (limitation of its termination), protection of remuneration, including in case of employer's lack of liquidity or bankruptcy (Baran 2019, p. 51). In the collective labour law, the protective function is expressed in the provisions defining the right to strike (in particular Art. 23 section 2 of the Act of 23 May 1991 on Dissolution of Collective Disputes, Dz.U. 2020, item 123 consolidated text, as amended), and in a wide scope referring to collective labour agreements that "many times are ... aimed at protection of economic and social interests of employees" (Baran 2019, p. 52). It is fulfilled by the provisions on operation of entities representing persons who perform work, e.g. trade unions as well (see more Baran 2002, pp. $399 \mathrm{ff}$ ). It is also expressed in the norms of process labour law that protects employee's interests, e.g. a possibility to obligate an employer for further employment of a worker until a valid decision on the case, a possibility to adjudge an alternative claim or imposing the immediate enforcement title ex officio to a ruling that is favourable for a worker (Baran 2019, p. 52).

In summary, only the institutions of labour law make it possible to achieve certain social objectives, including for instance to ensure fair conditions of work, a reduction of the unemployment level, combating poverty, counteracting social exclusion (Męcina 2015 , chapter 2.5 ). Socially responsible public procurement are inseparably connected with compliance with the provisions of the labour law, whose main aim is to protect the worker. It is expressed by the discussed requirement of employment under an employment relationship defined in the new Public Procurement Law.

\section{Summary}

To conclude the above discussion, it should be mentioned that through public procurement, the legislator fulfils objectives of the social policy according to the constitutional principle of social market economy and the protective function of the labour law connected with it. Promotion of employment under the employment relationships through the spending of public funds in relation to the execution of public contracts should be approved, and it is aimed at, for instance, counteracting unemployment, poverty, and supporting social inclusion.

At the same time doubts are raised in case of the obligation of a contracting authority, as the organiser of a public procurement procedure, in respect to the specification 
of type of activities, to which the obligation of employment under the employment relationship refers. A question should be asked whether the contracting authority is competent to determine the issues concerned. It should be also kept in mind that regardless of findings of the contracting authority, the employment relationship will be established in case of fulfilment of prerequisites specified in Art. $22 \$ 1$ of the Labour Code. Doubts refer also to the contracting authority's rights in the field of audit of an economic operator's (subcontractor's) fulfilment of the requirement of employment under the employment relationship at the stage of execution of a public contract. In this respect, the State Labour Inspection Office seems competent, since its responsibilities include supervision and control of compliance with the labour law, in particular with the provisions on the work safety and hygiene, as well as provisions on the legality of employment and other paid work.

The construction of the analysed requirement is a kind of interventionism justified by social reasons that restrict the freedom of the parties to determine a form of employment, protecting the weaker party of such legal relationship that is the one who performs work. Due to increasing wider enactment of provisions protecting all persons who perform work, regardless of the legal form, the modification of legal regulations in this respect should be considered. It could mean a reduction of obligations imposed on contracting authorities, and mainly specification of the types of activities subject to mandatory employment under an employment relationship. Undertaking legislative activities may also result from the fact that when the employee market is prevailing in relation to the employer market, the discussed requirement may result in an economic operator's resignation from applying for a public contract, since persons who perform work will not be interested in the conclusion of the employment relationship due to various reasons.

\section{References}

Baran K.W. (2002) O funkcjach zbiorowego prawa pracy uwag kilka [in:] M. Matey-Tyrowicz,

L. Nawacki, B. Wagner (red.), Prawo pracy a wyzwania XXI-go wieku. Ksiega jubileuszowa Profesora Tadeusza Zielińskiego, Warszawa.

Baran K.W. (2015) [in:] K.W. Baran (red.), System Prawa Pracy, t. 7: Zatrudnienie niepracownicze, LEX.

Baran K.W. (2019) [in:] K.W. Baran (red.), Prawo pracy i ubezpieczeń społecznych, Warszawa. Barnard C. (2012) EU Employment Law, Oxford.

Dzierżanowski W. (2012) Ochrona konkurencji w prawie zamówień publicznych, Warszawa.

Dzierżanowski W. (2017) Wymóg zatrudnienia pracowniczego przy realizacji zamówienia publicznego, "Prawo Zamówień Publicznych," No. 1.

Gersdorf M. (2018) [in:] M. Gersdorf, K. Rączka, W. Maniewska, M. Raczkowski, Prawo pracy. Pytania i odpowiedzi, Warszawa.

Granecki P. (2021) Prawo zamówień publicznych. Komentarz, Legalis.

Jacolik M. (2017) Podstawy społecznej gospodarki rynkowej z uwzględnieniem porzadku prawnego Unii Europejskiej, “Zeszyty Naukowe Prawa Konstytucyjnego,” No. 10. 
Lang G. (2014) Wymóg zatrudnienia na podstawie umowy o pracę w nowelizacji prawa zamówień publicznych z 29 sierpnia 2014 r., "Radca Prawny. Zeszyty naukowe," No. 1(2).

Lewandowski H., Góral Z. (1996) Przeciwdziałanie stosowaniu umów cywilnoprawnych do zatrudnienia pracowniczego, "Praca i Zabezpieczenie Społeczne," No. 12.

Matusiak A. (2021) [in:] M. Jaworska (red.), Prawo zamówień publicznych. Komentarz, Legalis.

Męcina J. (2015) [in:] K.W. Baran (red.), System Prawa Pracy, t. 7: Zatrudnienie niepracownicze, LEX.

Miętek A. (2019) Swoboda umów i jej ograniczenia przy kształtowaniu treści stosunku pracy, Legalis.

Moras M. (2016) Horyzontalna klauzula społeczna $w$ świetle nowych regulacji prawnych w zamówieniach publicznych, "Roczniki Administracji i Prawa," Vol. 16, Issue 2.

Moras M., Moras-Olaś K. (2017) Kontrola przestrzegania przepisów prawa pracy w trakcie realizacji umowy $w$ sprawie zamówienia publicznego $w$ prawie polskim i europejskim, "Monitor Prawniczy," No. 14.

Moras M., Moras-Olaś K. (2017) Wpływ polityki społecznej UE na regulacje dotyczace zamówień publicznych, "Praca i Zabezpieczenie Społeczne," No. 8.

Odachowski J. (2019) Socially Responsible Public Procurements as a State Policy Towards the Public Procurement Market (Context of the Public Supervision Over the Public Procurement Market), "Eurasian Journal of Economics and Finance," Vol. 7, No. 3.

Pisarczyk Ł. (2010) Przeobrażenia prawa pracy a jego funkcja ochronna [in:] B. Wagner, E. Hofmańska (red.), Studia prawnicze „Proaktywna” funkcja prawa pracy?, Kraków, https:// repozytorium.ka.edu.pl/bitstream/handle/11315/378/Studia_Prawnicze_Proaktywna_funkcja_prawa_pracy_2010.pdf?sequence=1\&isAllowed=y (access: 22 April 2021).

Piwowarczyk A. (2017) Wplyw wymogu zatrudniania na podstawie umowy o pracę w zamówieniach publicznych na sektor MŚP, "Prawo Zamówień Publicznych," No. 3.

Skąpski M. (2014) Realizacja idei społecznej gospodarki rynkowej w polskim ustroju pracy, "Ruch Prawniczy, Ekonomiczny i Socjologiczny," Vol. 76, Issue 2.

Skąpski M. (2016) Funkcje procesowego prawa pracy [in:] K.W. Baran (red.), System prawa pracy, t. 6: Procesowe prawo pracy, LEX.

Sobczyk A. (2013) Prawo pracy w świetle Konstytucji RP, t. 1: Teoria publicznego i prywatnego indywidualnego prawa pracy, Legalis.

Stelina J. (2017) [in:] K.W. Baran (red.), System prawa pracy, t. 1: Część ogólna, Warszawa.

Szostak R. (2017) Zagadnienia społeczne w zamówieniach publicznych, "Gdańskie Studia Prawnicze,”Vol. 37, https://prawo.ug.edu.pl/sites/default/files/_nodes/strona-pia/33461/ files/37szostak.pdf (access: 22 April 2021).

Świątkowski A.M. (2014) Autonomiczna definicja pracownika, "Monitor Prawa Pracy," No. 11. Świątkowski A.M. (2019) Uznanie za pracownika osoby zatrudnionej na podstawie umowy cywilnoprawnej, “Acta Universitatis Lodziensis. Folia Iuridica," Vol. 88, http://dx.doi. org/10.18778/0208-6069.88.05 (access: 22 April 2021).

Święcicki M. (1969) Prawo pracy, Warszawa.

Tomaszewska M. (2020) [in:] K.W. Baran (red.), Kodeks pracy. Komentarz, t. 1 (Art. 1-113), wyd. 5, LEX.

Wagner B. (2011) [in:] B. Wagner (red.), Kodeks pracy. Komentarz, Gdańsk. 


\section{Internet sources}

Communication From The Commission, Europe 2020, A strategy for smart, sustainable and inclusive growth, COM (2010) 2020 final, https://eur-lex.europa.eu/legal-content/EN/TXT/ PDF/?uri=CELEX:52010DC2020\&from=en (access: 22 April 2021).

UZP [Urząd Zamówień Publicznych, Public Procurement Office] (2017a) Informacja o wyniku kontroli doraźnej następczej, UZP/DKUE/KD/4/2017, https://www.uzp.gov.pl/_data/assets/ pdf_file/0026/35576/przebudowa-ul.-XXX-Lecia-PRL-i-ul.-Wesolej-w-Czarnym-Borze-f. pdf (access: 22 April 2021).

UZP (2017b) Opinia dotycząca art. 29 ust. 3 a ustawy Pzp uwzględniajaca wspólne stanowisko Prezesa Urzędu Zamówień Publicznych oraz Generalnego Inspektora Danych Osobowych $z$ dnia 28 kwietnia 2017 r., https://www.uzp.gov.pl/baza-wiedzy/interpretacja-przepisow/ opinie-archiwalne/pytania-i-odpowiedzi-dotyczace-nowelizacji-ustawy-prawo-zamowien-publicznych-2 (access: 22 April 2021).

UZP (2020), Sprawozdanie Prezesa Urzędu Zamówień Publicznych o funkcjonowaniu systemu zamówień publicznych w 2019 r., https://www.uzp.gov.pl/_data/assets/pdf_file/0020/43418/ Sprawozdanie-2019-r.pdf (access: 22 February 2021).

\section{Court sentences}

Decision of the Supreme Court of 12 September 2019, SN II UK 210/19, LEX 2763433.

Judgment of the CJEU of 1 October 2015, C-432/14, O v. Bio Philippe Auguste SARL, EU:C:2015:643.

Judgment of the National Appeal Chamber of 24 November 2016, KIO 2101/16.

Judgment of the National Appeal Chamber of 7 February 2017, KIO 191/17.

Judgment of the National Appeal Chamber 29 January 2018, KIO 74/18.

Judgment of the National Appeal Chamber of 22 October 2019, KIO 1988/19.

Judgment of the Supreme Court of 24 June 2015, II PK 189/14, Legalis 1303584.

Judgment of the Supreme Court of 18 February 2016, II PK 352/14, LEX 2004192.

Resolution of the Supreme Court of 9 September 1986, III PZP 37/86, OSN 1987, No. 9, item 134.

\section{Legal acts}

The Constitution of the Republic of Poland of 2 April 1997, Dz.U. 1997, No. 78, item 483 as amended.

Consolidated text of the Treaty on European Union, OJ C 2012/326, pp. 13-390.

Directive 96/71/EC of the European Parliament and of the Council of 16 December 1996 concerning the posting of workers in the framework of the provision of services, OJ L 1997/18, pp. 1-6.

Directive 2014/23/EU of the European Parliament and of the Council of 26 February 2014 on the award of concession contracts, OJ L 2014/94, pp. 1-64.

Directive 2014/24/EU of the European Parliament and of the Council of 26 February 2014 on public procurement and repealing Directive 2004/18/EC, OJ L 2014/94, pp. 65-242. 
Directive 2014/25/EU of the European Parliament and of the Council of 26 February 2014 on procurement by entities operating in the water, energy, transport and postal services sectors and repealing Directive 2004/17/EC, OJ L2014/ 94, pp. 243-374.

ILO [International Labour Organization] Convention 29 on Forced Labour, Dz.U. 1959, No. 20, item 122.

ILO Convention 87 on Freedom of Association and the Protection of the Right to Organise, Dz.U. 1958, No. 29, item 125.

ILO Convention 98 on the Right to Organise and Collective Bargaining, Dz.U. 1958, No. 29, item 126.

ILO Convention 100 on Equal Remuneration, Dz.U. 1955, No. 38, item 238.

ILO Convention 105 on the Abolition of Forced Labour, Dz.U. 1959, No. 39, item 240.

ILO Convention 111 on Discrimination (Employment and Occupation), Dz.U. 1961, No. 42, item 218.

ILO Convention 138 on Minimum Age, Dz.U. 1978, No. 12, item 53.

ILO Convention 182 on Worst Forms of Child Labour, Dz.U. 2004, No. 139, item 1474.

The Act of 23 May 1991 on Dissolution of Collective Disputes, Dz.U. 2020, item 123 consolidated text, as amended.

The Act of 10 June 1994 on Public Procurement Law, Dz.U. 2002, No. 72, item 664 consolidated text, as amended.

The Act of 29 January 2004 on Public Procurement Law, Dz.U. 2019, item 1843 consolidated text, as amended.

The Act of 27 August 2009 on Public Finance, Dz.U.2021, item 305 consolidated text, as amended. The Act of 29 August 2014 on amendment of the Public Procurement Law, Dz.U. 2014, item 1232. The Act of 22 June 2016 on amendment of the Public Procurement Law and other acts, Dz.U. 2016, item 1020.

The Act of 11 September 2019 on Public Procurement Law, Dz.U.2021, item 1129 consolidated text, as amended.

The Labour Code Act of 26 June 1974, Dz.U. 2020, item 1320 consolidated text, as amended. 